\title{
58
}

\section{When societies are built from bits}

\author{
William H. DAVIDOW, General Partner, Mohr, \\ Davidow Ventures, U.S.A.
}

Information age societies will look very different from our current ones. In the past what mattered most was geography, natural resources, and physical assets. In the future intangible assets will be king. The ability to process and move information will displace much of the physical infrastructure of society. Fewer office buildings, hotels, roads, and shopping malls will be needed. Businesses will be disintermediated, distribution channels will vanish, and the middle manstock brokers, retailers, distributors, travel agents, etc.will become increasingly less important. Of course the form and role of government will change as well. For example governments have gone to war to protect physical assets such as land that other countries wanted. In the future people will steal intellectual assets and governments will have no one to attack. Microsoft software, for example, is stolen by the citizens of China, not the government.

No one can predict the form that society will take in the future but it is possible to comprehend the forces that will be at work and the directions in which they will push society. Bill Davidow will describe some of the forces that will be at work and give some examples of how these forces might reshape societys social and physical infrastructure. 